\title{
Impact of China's Growing Global Position on the Economy of the Czech Republic
}

\author{
Kamila Veselá ${ }^{1, *}$, Linda Pudilová ${ }^{1}$ \\ ${ }^{1}$ Czech University of Life Sciences Prague, Faculty of Economics and Management, Department of \\ Economic Theories, Kamýcká 129, 165 00, Prague, Czech Republic
}

\begin{abstract}
.
Research background: The People's Republic of China in the 21st century can be described as an economy with high growth rates and great ambitions. Some statistics even indicate that China will become the world's new hegemon by 2040. The People's Republic of China is not only one of the largest exporters but is increasingly speaking to the world economy and international relations. Since the beginning of the 1990s, mutual relations between the People's Republic of China and the Czech Republic can be described as very good and constantly deepening, which can be evidenced, among other things, by the number of trade agreements.

Purpose of the article: Purpose of the article is to evaluate a development of mutual relations between Czech and Chinese economies in order to predict their future development. Emphasis will be placed on the development of mutual trade through the evaluation of absolute and relative indicators and growth rates.

Methods: The paper is based on secondary data from the database of the Czech Statistical Office. The key methods used in the article are the analysis of time series of real products of the Czech Republic and China and their foreign trade. The analysis focuses on the trend, deviations and development of absolute and relative indicators.

Findings \& Value added: The results of the analysis proved that the Chinese economy is growing on average more than twice as fast as the Czech economy. Because of that, the economic/living standards of the population of both countries are converging. The growth rate of the People's Republic of China, together with its high spending on science and research, means that (if this trend is maintained) China is likely to become the world's new hegemon in the near future.
\end{abstract}

Keywords: Czech Republic; China; economy; foreign trade; hegemon; trade policy

JEL Classification: $F 15 ; F 17, F 43$

*Corresponding author: veselakamila@pef.czu.cz 


\section{Introduction}

The rise of Chinese economy is an undeniable fact. The rate of PRC's grow is indeed so significant that many economists are speculating about the moment when Chine replaces USA as the world hegemon; the boldest among them mention the year 2030, others the year 2050. The growth of the Chinese economy does not manifest itself only as a growing GDP and improving living conditions enjoyed by the Chinese population, but primarily in the country's rising influence on the international scene and her impact on global politics and economy. One of those who analysed the crucial factors of China's rise was David Shambaugh [1]. He also pointed out a discrepancy in the country's foreign policy as China wants to join the ranks of world powers, becoming a hegemon on one hand, and remain a regional power on the other in order to keep her image and reputation as "the leader of the developing world". Compared to other states around the world, China is a country with a very specific culture. Her patriotism and concerns about retaining her specific cultural heritage in a globalised world follow in the footsteps of the 1970s when both the official and unofficial discourse expressed concerns about China's fate. [2]. Shambaugh [3] or Suzuki [4] were the ones to point out China's specific identity. The question of the degree to which a "modern" China is typical and traditional or open to the outside world, allowing a mingling with foreign cultures, was studied by Fürst [5]. Karmazin [6] concludes that the policy of developing the "Chinese dream" is not based on a re-evaluation of old principles and values and their transformation into new ones, rather on a creative combination of old and new factors.

China's efforts to become a world superpower are accompanied by a number of ambitious steps with respect to foreign policy [7, 8], such as the Belt and Road Initiative and its potential to become China's main strategy [9]. The issue of China's further course, including her role on the international stage, is studied by multiple authors, e.g. Das [10], Ferdinand [11], or Kerr [12]. Similarly, the Asian Infrastructure Investment Bank is considered by some economists to be China's most significant foreign policy measure since 1989 [13]. The bank is also the first international organisation created under the dominant influence of the People's Republic of China [14].

By means of analysis, the aim of this article is to evaluate PRC's global growth and her impact on the economy of the Czech Republic. The goal will be achieved by answering the following research questions:

Research questions 1: How are both economies developing and what's their current performance?

Research question 2: What is the PRC's position in regard to foreign-trade policy?

Research question 3: Are the Chinese and Czech economy prone to external shocks?

Research question 4: Is there a relationship of dependence between the performance of the

Czech and Chinese economy?

Research question 5: What is the attitude of the Czech Republic to China and Chinese goods.

\section{Methods}

This article uses secondary data, sourced mostly from the Czech Statistical Office and the World Bank. Analysis concerns the time series of the gross domestic product, expressed in American dollars, and the number of inhabitants which are then used to established the real GDP per capita. Time series for the period of 1990-2017 are analysed. The analysis examines the trend of the time series, deviations, and the development of absolute and relative indicators. This answers research question 1 . Research question 2 is answered by analysing China's representation in international organisations and her foreign policy 
measures. Research question 3 is also settled by analysing the time series of the gross domestic product of both economies, including deviations in times of external shocksprimarily 2009 , i.e. the period of the global financial-mortgage crisis. Research question 4 examines the correlation between the development of the gross domestic product of the Czech Republic and the People's Republic of China. The fifth question is answered by evaluating the development of Chinese exports and imports to the Czech Republic as a reflection of Czech demand for Chinese goods.

\section{Discussion}

Both the Chinese and Czech economy have experienced significant changes and a marked shift in their economic growth over the past 30 years. Chart No. 1 captures the development of the gross domestic product per capita from 1990 to 2017. In 1990, Chinese gross domestic product per capita in real terms amounted to 317.88 USD; in 2019, it was 10261.68 USD, equalling a growth of $3128 \%$. In 1990, the gross domestic product of the Czech Republic was 3917.16 USD; in 2019, it amounted to 23101.78 USD, equalling a growth of $490 \%$.

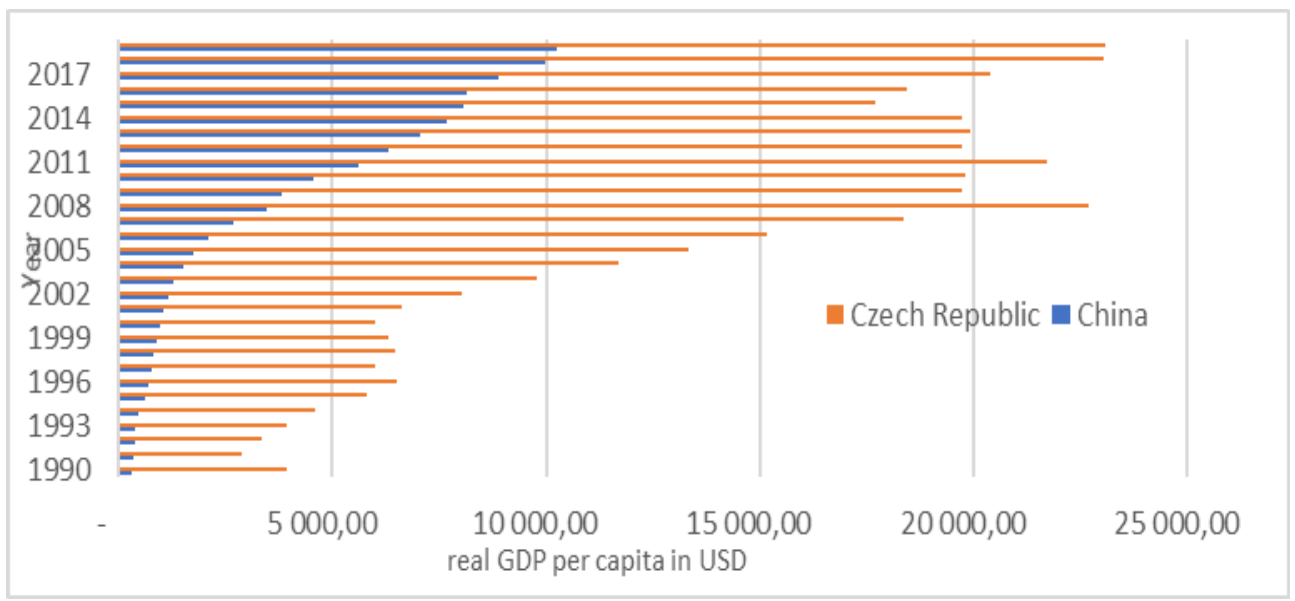

Fig. 1 Gross domestic product of China and the Czech Republic Source: Author's chart, data from the World Bank [15]

In 1990, the gross domestic product of the Czech Republic was 12.32 times higher than China's GDP; in 2019, it was 2.25 times higher than China's GDP. This comparison leads us to several clear conclusions - both economies experienced a relatively strong economic growth $(7.1 \%$ on average in case of the Czech economy, $13 \%$ in case of China). Clearly, the living standards are becoming similar and the gap between the level of development of both economies is closing. This also confirms the rise of the Chinese economy and that the country is headed to become a world power of a hegemonic force. Regarding the Czech Republic, there were observable cyclical fluctuations in reaction to negative external shocks which manifested itself, for example, by a decreasing rate of growth, or rather a $13 \%$ GDP decrease in 2009. In comparison, the Chinese economy showed a growing trend in times of recession.

The performance of both economies was analysed by means of correlation. No direct dependency of the performance of the Czech economy on the Chinese economy was established. The Czech Republic's foreign trade, however, is strongly affected by China, as Chinese imports constitute a significant portion of imports to the Czech Republic. And although Czech exports to China are low, they are positively growing. 
In the long term, the relationship between the Czech Republic and China has been positive, as evidenced by a number of aspects. The number of Chinese citizens living in the Czech Republic is shown in Chart No. 2. The chart leads us to several conclusions-1) the number of Chinese citizens living in the Czech Republic for long periods of time has been decreasing for some time; but 2) the total number of the Chinese living in the Czech Republic has been growing sharply; and 3) the number of the Chinese living in the Czech Republic short-term is growing.

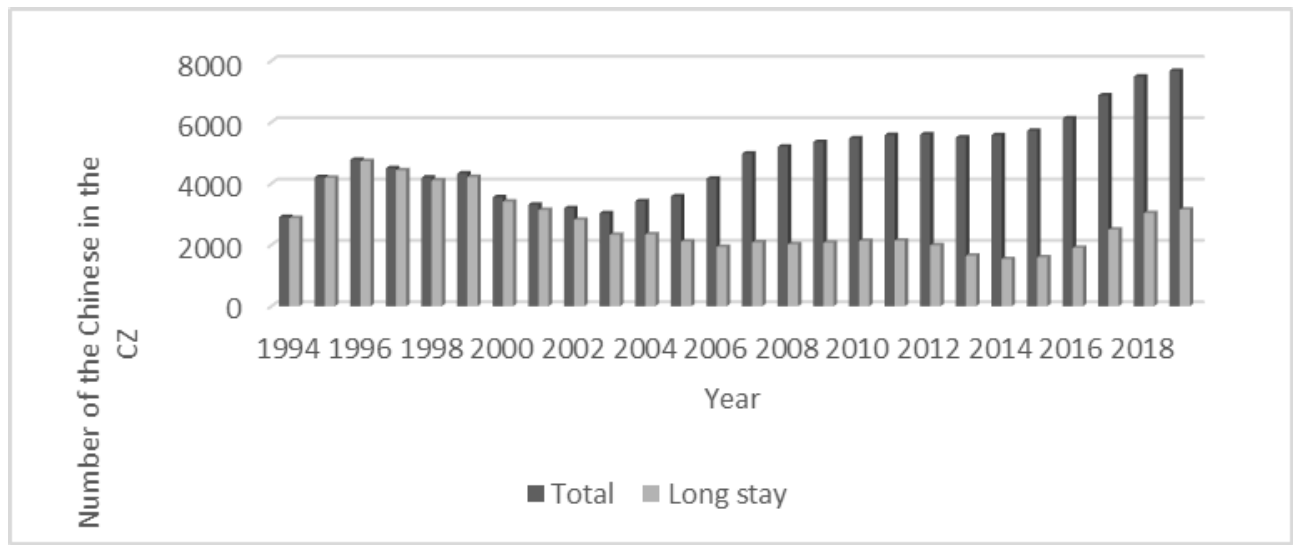

Fig. 2. Number of the Chinese living in the Czech Republic

Source: Author's chart, data from the Czech Statistical Office [16]

Once the Czech economy opened itself to the outside world and the possibility of foreign trade in 1989, trade between the Czech Republic and China began to develop. As shown by the next chart, foreign trade between the $\mathrm{CZ}$ and China had been growing over the reference period (ever since 1990), both in regard to imports and exports. It must be pointed out, however, that exports of Czech goods to China are minimal compared to imports as it is rather complicated for Czech producers to enter the Chinese market. This is caused mostly by the nature, mentality, and specificity of the People's Republic of China and the Chinese character. The Chinese market is largely closed to foreign producers; entering it usually requires years of preparation and negotiations which dissuades most Czech exporters [17].

Despite this, exports of Czech goods to China had been growing; for the reference period (2005-2019), the average annual increase amounted to $12.2 \%$. This is a result of Chinese efforts to develop the country's foreign policy, emphasising a positive relationship to the European Union and entailing the adoption of several documents to promote relations with the European Union and Czech Republic [18]. The political aspects of the EU-China cooperation in regard to energy are a specific matter, studied by Myšička [19]. 


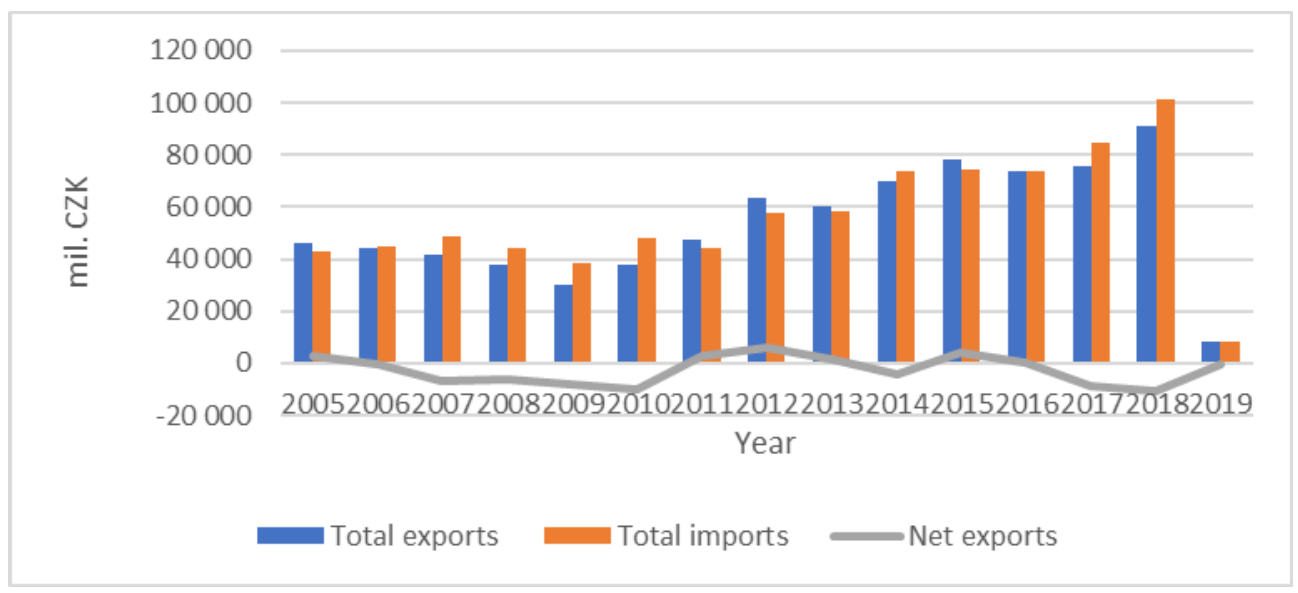

Fig. 3. Development of the CZ-China trade

Source: Author's chart, data from the Czech Statistical Office [16]

On the other hand, the Czech Republic welcomes Chinese imports. Since the Velvet Revolution and the market's opening to global competition in 1989, there has been an observable growth of Chinese imports to the Czech market. Although many view Chinese goods as poor or inferior in quality, this has been changing over the past years. Chinese research and technology investments are clearly becoming evident in the quality of Chinese goods. In 2003, Chinese research and development investments amounted to $1.31 \%$ GDP and have been quickly growing ever since. In 2017, the sum invested by China in science and research was "only" 50 billion lower than US investments. (China invested 500 billion USD, the United States of America 550 billion USD). On average, Chinese science and research expenses have increased by more than $17 \%$ annually in the 21 century. All this is caused by China's tendency, or rather efforts to become a world leader and have her economy, goods, and overall strength compete with the economy of USA, or rather every country in the world. Logically, the development of Chinese economy, increasing production, and mostly improving quality of goods have affected foreign trade with the Czech Republic. Czech exports to China are unequivocally dominated by machinery and means of transportation (these constituted $81.6 \%$ of total Czech exports to China in 1999; in 2019 , the percentage was only $55.6 \%$ ). This phenomenon can be explained not by a dropping value of the exports of transportation vehicles, but by increasing amounts of other products being exported, primarily raw materials and industrial goods. In the long-term, Czech imports from China have been dominated by machinery and means of transportation (over the past 20 years, their share in the total imports from China has grown from $36.4 \%$ to $80.1 \%$ ) where the development of Chinese technology, e-mobility, etc. we mentioned above is clearly evident. Industrial and consumer goods which constituted $40.3 \%$ of total imports from China in 1999 now constitute mere $12.4 \%$ of total imports.

The strength of the Chinese economy and its growing influence can also be demonstrated by China's increasing representation in global organisations. Currently, China has a leading role the Asian Infrastructure Investment Bank, Asian Development Bank, International Atomic Energy Agency, International Fund for Agricultural Development, International Monetary Fund, International Civil Aviation Organization, International Court of Justice, International Telecommunication Union, New Development Bank, United Nations Department of Economic and Social Affairs, The WTO Appellate Body, United Nations Industrial Development Organization, Food and Agriculture Organization of the United Nations, Organisation for the Prohibition of Chemical Weapons, Human Rights Council, World Bank, World Trade Organisation, World Health Organisation, and others. 


\section{Conclusion}

As some authors claim, Chinese economy is an economy and a future 21 st century hegemon. Some describe this as a fact, others as a danger. This article strived to draw conclusions on the basis of factual data on the strength of the Chinese economy and its effect on the economy of the Czech Republic. The Czech Republic is a small, open economy whose relationship to the People's Republic of China has long been positive. This is evident, for example, in the frequency with which both countries contractually define their relationship. Since 1952, China and the Czech Republic have entered into 33 bilateral agreements. The positive relationship of both economies is also observable in foreign trade which has doubled over the past 15 years, i.e. the share of Chinese imports in total imports to the Czech Republic grows each year.

Comparisons between the economy of the People's Republic of China and of the Czech Republic can be summarised thusly: Chinese economy grows at roughly a double rate of the Czech one. Thus, the economic/living conditions of both populations are becoming similar. The rate of PRC's growth, along with her significant science and research investments, will probably lead to China soon becoming a new world hegemon, provided that this trend holds in the future.

\section{References}

1. Shambaugh, D. (2003). China Goes Global: The Partial Power. Oxford University Press

2. Davies, G. (2007). Worrying about China: The Language of Chinese Critical Inquiry. Cambridge, Mass.: Harvard University Press.

3. Shambaugh, D. (2011). Coping with a Conflicted China. Washington Quarterly, 34(1), 7-27.

4. Suzuki, S. (2014). Journey to the West: China Debates Its "Great Power" Identity. Millennium, 42(3), 632-650.

5. Fürst, R. (2002). Čína na cestě od izolacionismu k plíživé globalizaci. Mezinárodní vztahy/Czech Journal of international relations, 2, 5-28.

6. Karmazin, A. (2017). Vytváření čínského snu: Proměna čínské politické modernity a zahraniční politiky. Mezinárodní vztahy/Czech Journal of international relations, 4, 48-67.

7. Callahan, W. (2015). History, Tradition and the China Dream: Socialist Modernization in the World of Great Harmony. Journal of Contemporary China, 24(96), 983-1001.

8. Callahan, W. (2015). Identity and Security in China: The Negative Soft Power of the China Dream. Politics, 35(3-4), 216-229.

9. Callahan, W. (2016). China's “Asia Dream": The Belt Road Initiative and the New Regional Order. Asian Journal of Comparative Politics, 1(3), 226-243.

10. Das, K. (2017). The Making of One Belt, One Road and Dilemmas in South Asia. China Report, 53(2), 125-142.

11. Ferdinand, P. (2016). Westawrd Ho - The China Dream and „One Belt, One Road“: Chinese Foreign Policy under Xi Jinping. International Affairs, 92(4), 941-957.

12. Kerr, D. (2015). China's Many Dreams: Comparative Perspectives on China's Search for National Rejuvenation. Basingstoke: Palgrave Macmillan.

13. Swaine, M.D. (2015). Chinese Views and Commentary on the "One Belt, One Road". China Leadership Monitor, 47. 
14. Swaine, M.D. (2014). Chinese Views and Commentary on Periphery Diplomacy. China Leadership Monitor, 44.

15. World bank. (2020). World Bank Open Data, Gross domestic product, population. Retrieved from: https://data.worldbank.org/

16. Czech Statistical office. (2020). Cizinci v $\check{C} R$ vč. Azylantů. Retrieved from: https://www.czso.cz

17. Pillsbury, M. (2019). Stoletý maratón - Tajná čínská strategie jak vystř́dat Ameriku v roli globální supervelmoci a nastolit čínský světový řád. Rybka Publishers.

18. Gregušová, G. (2005). Vztahy krajín Vesegrádskej štvorky s Čínou. Mezinárodní vztahy/Czech Journal of international relations, 1(1), 7-21.

19. Myšička, S. (2018). Spolupráce v energetické politice mezi Čínou a Evropskou unií, Mezinárodní vztahy/Czech Journal of international relations, 63(3), 75-91. 